\section{BRAZIULIAN JOURNAL \\ OF MEDICAL AND BIOLOGICAL RESF.ARCH}

www.bjournal.com.br
ISSN 0100-879X

Volume 43 (03) 226-324 March 2010

BIOMEDICAL SCIENCES

AND

CLINICAL INVESTIGATION

Braz J Med Biol Res, March 2010, Volume 43(3) 249-256

ApoE polymorphisms and diarrheal outcomes in Brazilian shanty town children

R.B. Oriá, P.D. Patrick, M.O.B. Oriá, B. Lorntz, M.R. Thompson, O.G.R. Azevedo, R.N.B. Lobo, R.F. Pinkerton, R.L. Guerrant and A.A.M. Lima

The Brazilian Journal of Medical and Biological Research is partially financed by
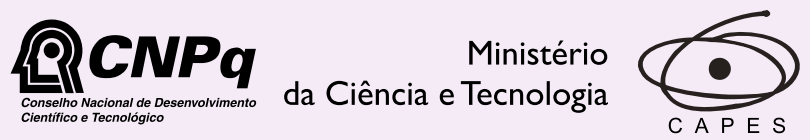

Ministério da Educação

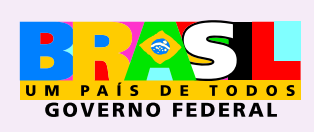

DFAPESP

Institutional Sponsors 


\title{
ApoE polymorphisms and diarrheal outcomes in Brazilian shanty town children
}

\author{
R.B. Oriáa ${ }^{3,4}$, P.D. Patrick², M.O.B. Oriá ${ }^{5}$, B. Lorntz ${ }^{4}$, \\ M.R. Thompson ${ }^{1}$, O.G.R. Azevedo ${ }^{4}$, R.N.B. Lobo6 ${ }^{6}$, R.F. Pinkerton ${ }^{1}$, \\ R.L. Guerrant ${ }^{1,4}$ and A.A.M. Lima ${ }^{1,4}$ \\ ${ }^{1}$ Center for Global Health, School of Medicine, ${ }^{2}$ Kluge Children's Rehabilitation and Research Center, \\ University of Virginia, Charlottesville, VA, USA \\ ${ }^{3}$ Departamento de Morfologia, ${ }^{4}$ Instituto de Biomedicina do Semi-árido Brasileiro (IBISAB), \\ Faculdade de Medicina, Universidade Federal do Ceará, Fortaleza, CE, Brasil \\ ${ }^{5}$ Departamento de Enfermagem, Universidade Federal do Ceará, Fortaleza, CE, Brasil \\ ${ }^{6}$ Centro de Pesquisa da EMPRAPA, Sobral, CE, Brasil
}

\begin{abstract}
A series of studies have shown that the heavy burdens of diarrheal diseases in the first 2 formative years of life in children living in urban shanty towns have negative effects on physical and cognitive development lasting into later childhood. We have shown that APOE4 is relatively common in shanty town children living in Brazil (13.4\%) and suggest that APOE4 has a protective role in cognitive development as well as weight-for-height in children with heavy burdens of diarrhea in early childhood (64/123; 52\%), despite being a marker for cognitive decline with Alzheimer's and cardiovascular diseases later in life. APOE2 frequency was higher among children with heaviest diarrhea burdens during the first 2 years of life, as detected by PCR using the restriction fragment length polymorphism method, raising the possibility that ApoE-cholesterol balance might be critical for growth and cognitive development under the stress of heavy diarrhea burdens and when an enriched fat diet is insufficient. These findings provide a potential explanation for the survival advantage in evolution of genes, which might raise cholesterol levels during heavy stress of diarrhea burdens and malnutrition early in life.
\end{abstract}

Key words: Apolipoprotein E; Malnutrition; Diarrhea; Children

\section{Introduction}

The vicious cycle between diarrhea and malnutrition is well known and may even occur with enteric infections without overt diarrhea (1). Furthermore, recent data from studies in Brazil and Peru have documented a lasting impact of diarrhea (as with malnutrition and intestinal helminthic infections) on child development with ill effects on cognition, growth, and educational performance $(2,3)$.

Apolipoprotein $E$ (Apoe) is a critical carrier protein, which delivers cholesterol to somatic cells and to the liver to be metabolized, therefore playing a crucial role in lipid homeostasis (4). The single structural locus of the human APOE gene has three alleles on chromosome 19: APOE2, APOE3, the most frequent allele in populations studied to date (4), and APOE4, which has been found to increase the risk for developing late-onset Alzheimer's disease (5). APOE4 bearers are more likely to have a poor prognosis fol- lowing cerebrovascular disease (6) and other forms of brain injury (7). However, the role of APOE alleles in cognitive development in pediatric populations is poorly explored.

Recent findings suggest that early cognitive development under the stresses of environmental toxins (8), early childhood diarrhea and malnutrition (9) may be protected by the APOE4 alleles, although not in healthy children in resource-rich countries (10), or even in shanty town children with low diarrhea burdens (11). Nevertheless, some studies have found an association of the APOE4 allele with better school performance and motor activity in children from developed countries (12), although some of these findings were not reproduced by others (13).

In the present study, we have updated our ongoing cohort project with new APOE polymorphism data focusing on the effect of APOE alleles during early development in

Correspondence: R.B. Oriá, Instituto de Biomedicina, Faculdade de Medicina, Universidade Federal do Ceará, Rua Coronel Nunes de Melo, 1315, Rodolfo Teófilo, 60430-270 Fortaleza, CE, Brasil. Fax: +55-85-3366-8445. E-mail: oria@ufc.br

Received September 10, 2009. Accepted January 21, 2010. Available online January 29, 2010. Published March 12, 2010. 
children afflicted with the stress of heavy diarrhea burdens and enteric infections, with a novel association with cognitive scores. Based on these findings, we suggest that genes that potentially raise cholesterol levels among non-exclusively breast-fed children receiving poor-fat diets might benefit adaptations and recovery from early childhood infection and malnutrition towards improved growth and cognition, despite the negative correlates with Alzheimer's and cardiovascular diseases later in life.

\section{Material and Methods}

\section{Population}

The study was conducted in the Gonçalves Dias community, a shanty town ("favela") located in Fortaleza (population estimated at 2.3 million), the capital city of the State of Ceará (population approximately 8 million), one of the poorest states in the Northeast of Brazil (Brazilian Institute of Geography and Statistics, refer to www.ibge.gov. br). The Gonçalves Dias community has been described in greater detail elsewhere (14). The children's population of this urban slum ( $<5$ years old) has a history of endemic diarrhea rates, which have been associated with seasonal rainfall and discontinuation of exclusive breast-feeding.

\section{Enteric infection and diarrhea survey}

During the study period, cups for the collection of stool specimens were distributed to the households of children with diarrhea. We used World Health Organization (WHO) guidelines to recognize an episode of diarrhea, as described in former cohort studies (15). One episode of diarrhea was defined as the excretion of three or more liquid or semiliquid stools during a 24-h period. A new episode was defined as diarrhea after $a \geq 48-h$ interval not meeting the diarrhea definition. Active surveillance for diarrhea episodes was performed three times a week by the field team visiting the community households. Recurrent and persistent episodes of diarrhea in this setting have been most significantly associated with Cryposporidium, Giardia, and enteroaggregative Escherichia coli infections (14). Human Investigation Committees at both the University of Virginia and at the Federal University of Ceará approved the study protocol. The parent/legal guardian of the eligible study children agreed to read and signed the approved consent form. A questionnaire was provided to assess socioeconomic and demographic data.

\section{Anthropometric measurements}

The field team consisting of a local nurse and 3 health workers conducted the anthropometric measurements. Height was measured with the child in the supine position to the nearest $0.1 \mathrm{~cm}$ with a measuring board. Height-perage $z$ score (HAZ), weight-per-age $z$ score (WAZ), and weight-per-height $\mathrm{z}$ score ( $\mathrm{WHZ})$, were calculated using the anthropometric Epi-Info software (Centers for Disease
Control, Atlanta, GA, USA), as markers of physical development and nutritional status. These anthropometric $z$ scores are the number of SD above or below the median values for the National Center for Health Statistics (NCHS) and International Reference Population (16). Each child was also screened for head circumference, since this parameter has been correlated with early postnatal cognitive development in other studies (16).

\section{Buccal cell collection and DNA extraction}

The buccal cell collection was conducted as described in Ref. 9. Briefly, the health worker asked the subject to brush the buccal surface 10 times on one side and then to expectorate the saliva into a $50-\mathrm{mL}$ sterile polypropylene centrifuge tube, repeating the process on the opposite side of the cheek. The subject then swished $10 \mathrm{~mL}$ water for $45 \mathrm{~s}$, with the health worker timing, and expectorated into the same $50-\mathrm{mL}$ tube, which was properly stored and delivered to the laboratory for processing. On the following day, the DNA from buccal cell samples was purified using a Gendra Puregene kit according to manufacturer instructions (Gendra System, USA).

\section{APOE genotyping}

The experimental protocol involved the amplification of APOE sequences from genomic DNA and digestion with the Hhal restriction enzyme (18). DNA from buccal cells was amplified by PCR in a thermal cycler using oligonucleotide primers F4 (5'-GCACGGCTGCCAAGGAGCTG CAGGC-3') and F6 (5'-GGCGCTCGCGGATGGCGCTG AG-3'), as described elsewhere (19). The PCR master mix with Taq polymerase and nucleotide components was obtained from Roche Molecular Biochemicals, USA. Each amplification reaction contained about $1 \mu \mathrm{g}$ buccal cell DNA, $1-2 \mu \mathrm{M}$ of each primer, and $10 \%$ DMSO in a final volume of $50 \mu \mathrm{L}$. The PCR conditions included an initial step at $95^{\circ} \mathrm{C}$ for $4 \mathrm{~min}, 62^{\circ} \mathrm{C}$ for $30 \mathrm{~s}$ and $72^{\circ} \mathrm{C}$ for $1 \mathrm{~min}$, followed by 39 cycles $\left(95^{\circ} \mathrm{C}, 15 \mathrm{~s} ; 62^{\circ} \mathrm{C}, 15 \mathrm{~s} ; 70^{\circ} \mathrm{C}, 15 \mathrm{~s}\right)$, and by a final extension at $72^{\circ} \mathrm{C}$ for 3 min with a $4^{\circ} \mathrm{C}$ hold. The uncut amplification products, $10 \mu \mathrm{L}$ of the $50 \mu \mathrm{L}$ PCR product, were electrophoresed onto $2 \%$ Ultrapure agarose gel (Invitrogen, USA), containing $0.4 \mu \mathrm{g} / \mathrm{mL}$ ethidium bromide and 1.0X Tris-acetate-EDTA (TAE). After PCR amplification, 5 units Hhal (New England BioLabs, USA) were added directly to each reaction mixture for digestion of APOE sequences $\left(3 \mathrm{~h}\right.$ at $\left.37^{\circ} \mathrm{C}\right)$. Each reaction mixture was loaded onto a $4 \%$ agarose gel ( $3 \%$ Nursuive GTG gel $+1 \%$ Ultrapure gel), containing ethidium bromide in $0.5 \mathrm{X}$ Tris-borate-EDTA (TBE) and electrophoresed for $1 \mathrm{~h}$ under constant voltage (100 V). The gel was cast on a $10-\mathrm{x} 15-$ $\mathrm{cm}$ tray. After electrophoresis, digested fragments were visualized by UV illumination. The sizes of Hhal fragments were estimated by comparison with known DNA ladders. Ambiguous APOE genotypes were further differentiated by either repeating the former protocol, after a series of 
DNA dilutions or by DNA sequencing after purifying the amplicons (Qia-Quick PCR Purification Kit, Qiagen, USA) generated by a forward primer as originally described by Hixson and Vernier (17).

\section{Cognitive tests}

A short battery of cognitive tests was selected based on their ability to evaluate executive function, IQ and language skills and on easy acceptance by the study children. These tests $(18,19)$ have been successfully used, among others, in our prior studies with Gonçalves Dias children of a similar age range. The short battery was applied in a standardized manner with instructions given in Portuguese in a quiet room by a nurse trained by the study neuropsychologist and assisted by the field health workers. The battery chosen included only three subtests: verbal fluency (semantic + phonetic fluency), WISC-III coding subtest, and the test of nonverbal intelligence III (TONI-III, Pro-Ed, USA). All cognitive tests were applied blindly regarding the children's diarrhea history. The verbal fluency tests were applied according to the NEPSY Developmental Neuropsychological Assessment booklet (The Psychological Corporation, USA), in order to assess the ability to generate words in semantic categories and with phonetic constraints $(9,19)$. The total score was obtained by the number of words said, excluding proper names and avoiding words that did not belong to the category requested. In the coding test, paired associated symbol recall was determined according to the standard WISC-III (The Psychological Corporation) to evaluate visual short-term memory and psychomotor skills. The child was required to remember symbols associated with specific digits and to draw the corresponding symbol for each digit. The coding subtest scores the total number of errors in a 120-s trial and the number of correctly drawn symbols at each 30-s interval. The child was awarded 1 point for each correctly drawn symbol. The total raw score was converted to a scaled score according to the WISC-III record form.

\section{Statistical analysis}

Data were analyzed with the SPSS statistical software package (SPSS, Inc., USA). Allelic frequencies were determined by counting different alleles and calculating their proportions. Demographic characteristics were described in terms of rates and percentages. Analyses of contingency tables were used to investigate categorical variables using the $\mathrm{X}^{2}$ test corrected by Mantel-Haenszel or the Fisher exact test. In order to determine whether the observed allele frequencies agreed with those expected, frequencies were input to confirm the hypothesis of Hardy-Weinberg equilibrium, using a $x^{2}$ goodness-of-fit test. Multilinear regression and correlation analyses were performed to avoid other potential confounders, controlling for malnutrition indicators, socioeconomic status, mother's educational level, and intestinal parasites. The unpaired Student $t$-test was used for continuous terms. $\mathrm{P}<0.05$ was considered to be statistically significant.

\section{Results}

In order to understand how APOE polymorphisms may contribute to adaptations after environmental challenges, we conducted APOE genotyping in Brazilian children under active cohort surveillance after birth with different histories of diarrhea burdens in their first two years of life. Building upon preliminary results for 72 children, we now have 123 cohort children (246 alleles) that confirm and strengthen our findings that APOE4 protects shanty town children against heavy diarrhea outcomes, and among those with heavy diarrhea it protects against the long-term cognitive sequelae of the condition. No statistical difference was found in the sociodemographic profile of the total study cohort regarding the APOE alleles in the total population, i.e., neither APOE4 children (who harbor genotypes 2/4, 3/4, 4/4) nor APOE3 children (who harbor genotypes $3 / 3,2 / 3,3 / 4$ ) or APOE2 children (who harbor genotypes $2 / 2,2 / 3$, and $2 / 4$ ) differed in their cohort characteristics, social backgrounds and nutritional status on average (Table 1). Nevertheless, now with a larger number of subjects, it is noteworthy that we could find a higher frequency of allele 4 among children with higher $\mathrm{WHZ}$ at two years of age in the total population and in the group with heaviest diarrhea burdens (Table 2).

Overall, we detected a slightly higher frequency of the APOE4 allele than expected (13.41 vs $10-12 \%$ expected) and an increased frequency in children with lower diarrhea burdens (15.83\%) vs those with heavier diarrhea burdens (11.29\%). We also noted a significantly higher occurrence of the APOE2 allele among children with heavy diarrhea burdens (9.38 vs $2.59 \%$ with lower diarrhea; $\mathrm{P}<0.033$ ), as shown in Table 2. By comparing the heterozygosis between the 2/3 and 3/4 genotypes, shown in bold in Table 2 (meaning one change from allele 2 to allele 4 , and assuming that allele 3 is neutral), children carrying the $2 / 3$ genotype exhibit a 3-fold higher relative risk to present heavy diarrhea than children bearing the $2 / 4$ genotype $(P=0.04 ; 95 \% \mathrm{Cl}=$ 0.9520 to 10.02 , by the chi-square analysis). This supports the opposite effect of alleles 2 and 4 on enteric diarrheal illnesses as observed for the risk of Alzheimer's disease, but in a different direction (20), with allele 4 shifting to a more protective effect and allele 2 shifting to an increased risk of diarrhea. In order to determine whether the two groups stratified according to diarrheal episodes showed genetic similarity regarding their APOE gene, we analyzed them independently (light and heavy diarrheal groups) to find out whether they departed from the Hardy-Weinberg equilibrium. We observed that both groups independently obeyed Hardy-Weinberg equilibrium (see Table 3), thus allowing socio-sanitary and cognitive associations regarding allelic and genotypic distribution in the two stratified subsets of the study population. 
Table 1. Demographic and anthropometric data of the study population according to APOE alleles $(N=123)$.

\begin{tabular}{|c|c|c|c|}
\hline Cohort characteristics & APOE4 & APOE3 & APOE2 \\
\hline Mean age (months) & $104.81 \pm 20.52(31)$ & $98.04 \pm 18.22(77)$ & $107.72 \pm 22.12(14)$ \\
\hline Head circumference $(\mathrm{cm})$ & $54.24 \pm 1.89(21)$ & $53.41 \pm 2.04(37)$ & $53.41 \pm 2.43(11)$ \\
\hline Birth weight $(\mathrm{kg})$ & $3.31 \pm 0.48(30)$ & $3.17 \pm 0.44(74)$ & $3.16 \pm 0.48(14)$ \\
\hline Birth length $(\mathrm{cm})$ & $49.40 \pm 3.49(30)$ & $49.35 \pm 2.26(74)$ & $49.63 \pm 2.68(13)$ \\
\hline \multicolumn{4}{|l|}{ Gender } \\
\hline Male & $10(32.2 \%)$ & $32(41.5 \%)$ & $6(42.9 \%)$ \\
\hline Female & $21(67.8 \%)$ & $45(58.5 \%)$ & $8(57.1 \%)$ \\
\hline \multicolumn{4}{|l|}{ Nutritional status } \\
\hline HAZ 0 & $-0.18 \pm 1.92(30)$ & $-0.11 \pm 0.89(74)$ & $-0.04 \pm 1.02(13)$ \\
\hline WAZ 0 & $-0.22 \pm 0.93(30)$ & $-0.51 \pm 0.80(74)$ & $-0.53 \pm 0.90(14)$ \\
\hline WHZ 0 & $-0.14 \pm 0.75(29)$ & $-0.25 \pm 0.93(72)$ & $-0.49 \pm 1.13(13)$ \\
\hline HAZ 12 & $-1.63 \pm 3.09(28)$ & $-1.35 \pm 2.77(70)$ & $-0.85 \pm 0.82(13)$ \\
\hline WAZ 12 & $-0.27 \pm 3.41(28)$ & $-0.15 \pm 3.05(70)$ & $-0.28 \pm 1.28(13)$ \\
\hline WHZ 12 & $0.39 \pm 1.09(27)$ & $0.50 \pm 1.36(68)$ & $0.89 \pm 1.15(13)$ \\
\hline HAZ 24 & $-0.97 \pm 1.28(23)$ & $-0.79 \pm 1.10(58)$ & $-0.96 \pm 0.74(10)$ \\
\hline WAZ 24 & $-1.14 \pm 1.22(23)$ & $-0.65 \pm 1.22(58)$ & $-0.54 \pm 1.23(10)$ \\
\hline WHZ 24 & $-0.41 \pm 1.17(22)$ & $0.07 \pm 1.17(56)$ & $0.36 \pm 1.04(10)$ \\
\hline Days breast-fed & $65.04 \pm 62.09(27)$ & $73.53 \pm 61.52(72)$ & $76.36 \pm 66.34(14)$ \\
\hline \multicolumn{4}{|l|}{ Disease burden } \\
\hline Episodes of diarrhea & $6.84 \pm 7.36(31)$ & $7.68 \pm 5.97(77)$ & $9.64 \pm 5.33(14)$ \\
\hline Days of observation & $754.11 \pm 236.47(28)$ & $812.35 \pm 326.70(71)$ & $913.14 \pm 505.98(14)$ \\
\hline Mean epis/obs ratio & $3.64 \pm 3.95(28)$ & $3.81 \pm 3.16(71)$ & $4.20 \pm 2.25(14)$ \\
\hline \multicolumn{4}{|l|}{ Maternal education level } \\
\hline Below primary school & $19(76 \%)$ & $36(69.2 \%)$ & $9(69.2 \%)$ \\
\hline Primary school or above & $6(24 \%)$ & $12(23.1 \%)$ & $2(15.4 \%)$ \\
\hline Unknown & $0(0 \%)$ & $4(7.7 \%)$ & $2(15.4 \%)$ \\
\hline \multicolumn{4}{|l|}{ Socioeconomic status } \\
\hline Rooms per household & $2.24 \pm 1.50(29)$ & $2.07 \pm 0.91(72)$ & $2.14 \pm 0.95(14)$ \\
\hline Income, in minimum wages ${ }^{a}$ & $5.44 \pm 2.03(25)$ & $5.58 \pm 2.03(52)$ & $4.38 \pm 2.33(13)$ \\
\hline$<2$ & $2(8 \%)$ & $2(3.8 \%)$ & $2(15.4 \%)$ \\
\hline$\geq 2$ & $23(92 \%)$ & $50(96.2 \%)$ & $11(84.6 \%)$ \\
\hline
\end{tabular}

Cohort data, when available, are reported as means $\pm S D(N)$. Gender, maternal education level, and income data are reported as $\mathrm{N}(\%)$. HAZ = height-per-age $\mathrm{z}$ score; WAZ = weightper-age $z$ score; $W H Z$ = weight-per-height $z$ score $(0=$ at birth, $12=$ at 12 months; $24=$ at 24 months). $Z$ scores represent standard deviations above or below the reference population mean. Epis/Obs ratio = number of episodes/observed days. ${ }^{\text {aNumber }}$ of minimum wages per month: 1 minimum wage $=$ US $\$ 102 /$ month (at the time of the study). APOE4 $=$ children carrying one or more E4 allele (genotypes: 2/4, 3/4, 4/4); APOE2 = children carrying one or more E2 allele (genotypes: $2 / 3,2 / 4,2 / 2$ ). APOE3 = children carrying one or more E3 allele (genotypes: 2/3, 3/4, 3/3).

Table 2. ApoE genotype and allele frequencies (f) of cohort children (6-12 years old) with different diarrhea burdens in the Gonçalves Dias shanty town, Fortaleza, Northeastern Brazil $(\mathrm{N}=123)$.

\begin{tabular}{|c|c|c|c|c|c|c|c|c|c|}
\hline \multirow[t]{2}{*}{ APOE } & \multicolumn{6}{|c|}{ Genotypes } & \multicolumn{3}{|c|}{ Alleles } \\
\hline & $2 / 2$ & $2 / 3$ & $3 / 3$ & $2 / 4$ & $3 / 4$ & $4 / 4$ & 2 & 3 & 4 \\
\hline Group 1, N (f\%) & $1(1.56)$ & $8(12.50)$ & $41(64.06)$ & $2(3.13)$ & 11 (17.19) & $1(1.56)$ & $12(9.38)^{*}$ & $101(78.90)$ & $15(11.72)$ \\
\hline Group 2, N (f\%) & $0(0.0)$ & $3(5.09)$ & $37(62.71)$ & $0(0.0)$ & $19(32.20)$ & $0(0.0)$ & $3(2.54)$ & 97 (82.21) & $18(15.25)$ \\
\hline Total, N (f\%) & $1(0.81)$ & $11(8.94)$ & $78(63.41)$ & $2(1.63)$ & 30 (24.39) & $1(0.81)$ & $15(6.10)$ & $198(80.49)$ & $33(13.41)$ \\
\hline
\end{tabular}

Group $1=$ cohort children with $\geq$ the median number of diarrheal episodes $(N=64)$; group $2=$ cohort children with $<$ the median number of diarrheal episodes $(N=59)$. Median episodes of diarrhea in the first 2 years of life $=2.77$. See 2 nd paragraph of Results for explanation of bold type. ${ }^{*} \mathrm{P}=0.033, \mathrm{X}^{2}=4.861, \mathrm{OR}=3.897,95 \% \mathrm{Cl}=1.071$ to 14.17 (Fisher exact test). 
Table 3. Independent Hardy-Weinberg equilibrium analyses of the study groups according to burdens of diarrheal episodes in their first two years of life.

\begin{tabular}{lcc}
\hline \multicolumn{3}{c}{ Group 1 - Children with $\geq$ the median of diarrheal episodes $(\mathrm{N}=64)$} \\
\hline Allele E2 $(\mathrm{f})$ & Alelle E3 $(\mathrm{f})$ & Allele E4 $(\mathrm{f})$ \\
0.093 & 0.789 & 0.117 \\
Genotypes & Expected values & Observed values \\
$2 / 2$ & 0.562 & 1 \\
$2 / 3$ & 9.468 & 8 \\
$2 / 4$ & 1.406 & 2 \\
$3 / 3$ & 39.847 & 41 \\
$3 / 4$ & 11.835 & 11 \\
$4 / 4$ & 0.878 & 1 \\
$X^{2}=0.927(P>0.05)$ & & \\
\hline
\end{tabular}

Group 2 - Children with $<$ the median of diarrheal episodes $(N=59)$

\begin{tabular}{lcc}
\hline Allele E2 (f) & Alelle E3 (f) & Allele E4 (f) \\
0.025 & 0.822 & 0.152 \\
Genotypes & Expected values & Observed values \\
$2 / 2$ & 0.038 & 0 \\
$2 / 3$ & 2.466 & 3 \\
$2 / 4$ & 0.457 & 0 \\
$3 / 3$ & 39.868 & 37 \\
$3 / 4$ & 14.796 & 19 \\
$4 / 4$ & 1.372 & 0 \\
$X^{2}=3.384(P>0.05)$ & & \\
\hline
\end{tabular}

Neither group 1 nor group 2 showed Hardy-Weinberg disequilibrium, therefore there were no significant differences between observed and expected frequencies regarding the APOE gene. Thus, it was possible to perform genetic comparisons between them since both groups showed genetic similarities for this gene locus.
Progressive reductions in diarrhea burdens (according to diarrhea quartiles) were seen with APOE alleles 2, 3 , and 4 by linear-by-linear association $(P=0.03)$, further confirming this relationship according to the following order: E2 $>$ E3 $>$ E4 (Figure 1).

When we examined the children who experienced the heaviest diarrhea burdens ( $\geq$ the median number of 2.77 diarrheal episodes/cohort observed days, during the first 2 years of life), we found a higher frequency of the E4 allele among children with better coding scores (higher than the median of the coding scores for the study cohort children), as shown in Table 4. Children with heavy diarrhea burdens in the first two years of life had a 5-fold higher chance to perform better in the WISC-III coding test. A trend towards a higher frequency of the APOE4 allele was seen among the group of higher TONI-III, albeit without reaching statistical significance.

\section{Discussion}

ApoE, a 35-kDa plasma protein synthesized mainly in the liver, is involved in cholesterol transport and metabolism. ApoE is also expressed in other tissues, notably the brain, which is the second most prolific tissue in terms of ApoE production (20-22).

ApoE isoforms influence serum lipid levels, cardiovascular disease, and neuronal repair (20). Individuals with the APOE4 allele have a markedly increased risk to develop early- and late-onset Alzheimer's disease and poor recovery after brain injury in adults (5). Defects in brain plasticity and neuronal death have been associated with increased rates of tau phosphorylation, neurofibrillary tangle and senile amyloid deposit (21). However, to date few studies have addressed the role of APOE polymor-

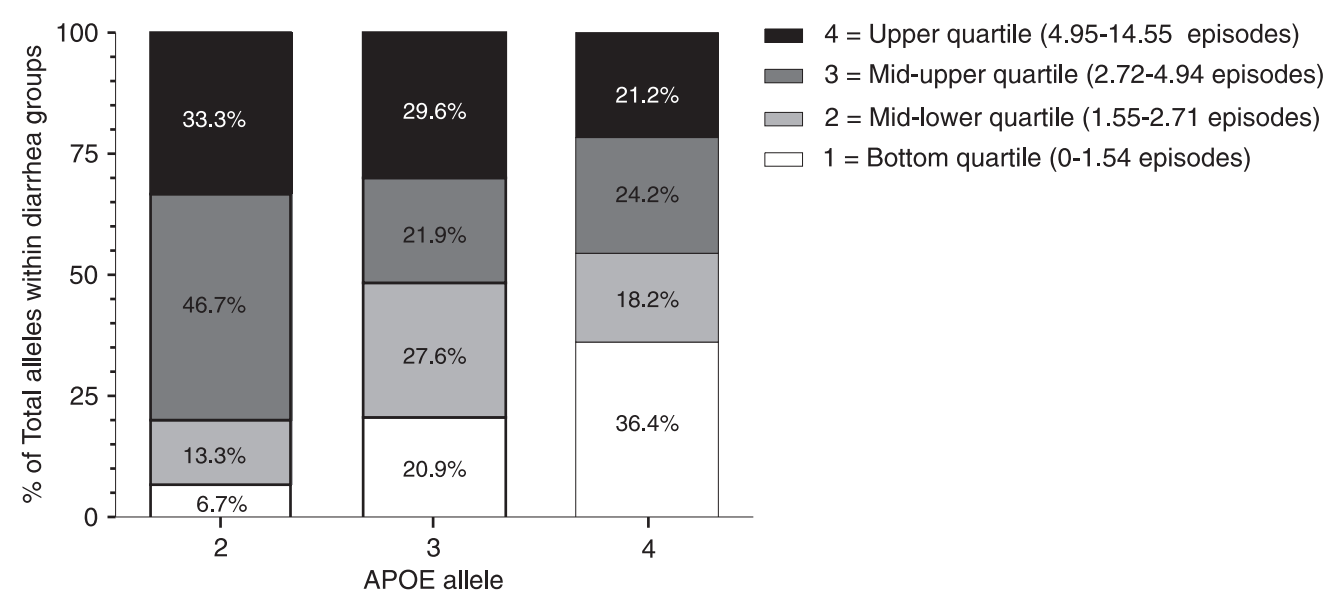

Figure 1. Progressive reductions in diarrhea with APOE alleles 2,3 , and $4(P=0.03)$, linear-by-linear association. $\mathrm{N}=246$ alleles in 123 cohort children. 
Table 4. Cognitive and anthropometric scores and allele 4 frequency in Gonçalves Dias children, Northeastern Brazil.

\begin{tabular}{|c|c|c|c|c|c|c|c|c|c|c|c|c|c|c|c|c|c|c|}
\hline & \multicolumn{6}{|c|}{ Total study population } & \multicolumn{6}{|c|}{ Children with heavy diarrhea burdens } & \multicolumn{6}{|c|}{ Children with low diarrhea burdens } \\
\hline & $\begin{array}{c}\text { APOE4(+) } \\
\text { N (f\%) }\end{array}$ & $\begin{array}{l}\text { APOE4(-) } \\
\text { N (f\%) }\end{array}$ & OR & $95 \% \mathrm{Cl}$ & $x^{2}$ & $P$ & $\begin{array}{c}\text { APOE4(+) } \\
\mathrm{N}(\mathrm{f} \%)\end{array}$ & $\begin{array}{c}\text { APOE4(-) } \\
\text { N (f\%) }\end{array}$ & OR & $95 \% \mathrm{Cl}$ & $x^{2}$ & $P$ & $\begin{array}{c}\text { APOE } 4(+) \\
\text { N (f\%) }\end{array}$ & $\begin{array}{c}\text { APOE4(-) } \\
\text { N (f\%) }\end{array}$ & OR & $95 \% \mathrm{Cl}$ & $x^{2}$ & $P$ \\
\hline \multicolumn{19}{|c|}{ Cognitive profile } \\
\hline $\begin{array}{l}\text { TONI III } \\
>\text { median }\end{array}$ & $18(17.31)$ & $86(82.69)$ & 2.16 & $\begin{array}{l}0.92 \\
\text { to } 5.07\end{array}$ & 3.25 & 0.098 & $9(19.6)$ & $37(80.4)$ & 2.96 & $\begin{array}{c}0.92 \\
\text { to } 9.53\end{array}$ & 3.56 & 0.082 & $9(15.5)$ & $49(84.5)$ & 1.469 & $\begin{array}{l}0.41 \\
\text { to } 5.17\end{array}$ & 0.36 & 0.76 \\
\hline $\begin{array}{l}\text { TONI III } \\
\leq \text { median }\end{array}$ & $9(8.82)$ & $93(91.18)$ & & & & & $5(7.6)$ & $61(92.4)$ & & & & & $4(11.1)$ & $32(88.9)$ & & & & \\
\hline $\begin{array}{l}\text { Fluency } \\
>\text { median }\end{array}$ & $23(16.20)$ & $119(83.80)$ & 1.86 & $\begin{array}{l}0.82 \\
\text { to } 4.23\end{array}$ & 2.29 & 0.130 & $10(15.2)$ & $56(84.8)$ & 2.41 & $\begin{array}{c}0.71 \\
\text { to } 8.15\end{array}$ & 2.10 & 0.121 & $13(17.1)$ & $63(82.9)$ & 1.362 & $\begin{array}{l}0.44 \\
\text { to } 4.14\end{array}$ & 0.29 & 0.78 \\
\hline $\begin{array}{l}\text { Fluency } \\
\leq \text { median }\end{array}$ & $9(9.38)$ & $87(90.62)$ & & & & & $4(6.9)$ & $54(93.2)$ & & & & & $5(13.2)$ & $33(86.8)$ & & & & \\
\hline $\begin{array}{l}\text { Coding } \\
>\text { median }\end{array}$ & $18(19.15)$ & $76(80.85)$ & 2.48 & $\begin{array}{l}1.02 \\
\text { to } 6.04\end{array}$ & 4.22 & 0.056 & $9(21.4)$ & $33(78.6)$ & 5.18 & $\begin{array}{c}1.31 \\
\text { to } 20.49\end{array}$ & 6.424 & $0.025^{*}$ & $9(17.3)$ & $43(82.7)$ & 1.24 & $\begin{array}{l}0.34 \\
\text { to } 3.73\end{array}$ & 0.04 & 1.0 \\
\hline $\begin{array}{l}\text { Coding } \\
\leq \text { median }\end{array}$ & $8(8.70)$ & $84(91.30)$ & & & & & $3(5.0)$ & $57(95.0)$ & & & & & $5(15.6)$ & $27(84.4)$ & & & & \\
\hline \multicolumn{19}{|c|}{ Anthropometrics } \\
\hline $\begin{array}{l}\text { HAZ } 24 \\
>\text { median }\end{array}$ & $12(10.53)$ & $102(89.47)$ & 0.60 & $\begin{array}{l}0.27 \\
\text { to } 1.30\end{array}$ & 1.68 & 0.247 & $5(9.62)$ & $47(90.38)$ & 0.638 & $\begin{array}{c}0.20 \\
\text { to } 1.99\end{array}$ & 0.60 & 0.580 & $7(11.29)$ & $55(88.71)$ & 0.604 & $\begin{array}{l}0.17 \\
\text { to } 1.52\end{array}$ & 1.43 & 0.27 \\
\hline $\begin{array}{l}\text { HAZ } 24 \\
\leq \text { median }\end{array}$ & 19 (16.38) & $97(83.62)$ & & & & & $10(14.29)$ & $60(85.71)$ & & & & & $9(19.57)$ & $37(80.43)$ & & & & \\
\hline $\begin{array}{l}\text { WAZ } 24 \\
>\text { median }\end{array}$ & $12(10.71)$ & $100(89.29)$ & 0.64 & $\begin{array}{l}0.29 \\
\text { to } 1.39\end{array}$ & 1.26 & 0.328 & $5(9.26)$ & $49(90.74)$ & 0.624 & $\begin{array}{c}0.19 \\
\text { to } 1.97\end{array}$ & 0.64 & 0.570 & $7(12.07)$ & $51(87.93)$ & 0.625 & $\begin{array}{l}0.21 \\
\text { to } 1.82\end{array}$ & 0.74 & 0.42 \\
\hline $\begin{array}{l}\text { WAZ } 24 \\
\leq \text { median }\end{array}$ & 18 (15.79) & $96(84.21)$ & & & & & $9(14.06)$ & $55(85.94)$ & & & & & $9(18.00)$ & $41(82.00)$ & & & & \\
\hline $\begin{array}{l}\text { WHZ } 24 \\
>\text { median }\end{array}$ & $21(18.75)$ & 91 (81.3) & 2.66 & $\begin{array}{l}1.16 \\
\text { to } 6.11\end{array}$ & 5.66 & $0.019^{*}$ & $11(19.64)$ & $45(80.36)$ & 5.05 & $\begin{array}{c}1.33 \\
\text { to } 19.16\end{array}$ & 6.64 & $0.020^{*}$ & $10(17.86)$ & $46(82.14)$ & 1.522 & $\begin{array}{l}0.50 \\
\text { to } 4.54\end{array}$ & 0.57 & 0.58 \\
\hline $\begin{array}{l}\text { WHZ } 24 \\
\leq \text { median }\end{array}$ & $9(7.96)$ & $104(92.04)$ & & & & & $3(4.62)$ & $62(95.38)$ & & & & & $6(12.50)$ & $42(87.50)$ & & & & \\
\hline
\end{tabular}

Median number of diarrheal episodes $=2.77$. OR = odds ratio; $95 \% \mathrm{Cl}=95 \%$ confidence interval, by $\mathrm{X}^{2}$ analyses. TONI III $=$ test of nonverbal intelligence III; fluency = total fluency includes scaled scores for both semantic and phonetic fluency cognitive tests; coding $=$ children under 8 mark rows of shapes with different lines according to a code number; HAZ = height-per-age $z$ score; WAZ = weightper-age $\mathrm{z}$ score; $\mathrm{WHZ}$ = weight-per-height $\mathrm{z}$ score.

phism early in life, especially following an environmental challenge.

In our studies of shanty town children in Northeast Brazil, we found that early childhood diarrhea and enteric parasitic infections are associated with significant, long-term cognitive deficits in certain higher executive function, such as verbal fluency and coding, and that the APOE4 allele is associated with protection against these deficits $(9,23)$. In a recent study, Wright et al. (8) found that APOE4 in Mexico City children associates with $>4.4$ points better Bayley Mental Developmental Index scores at 24 months of age and with a 4-fold protection from the adverse effects of lead, supporting the hypothesis that APOE polymorphisms may influence early developmental milestones in an opposite direction than seen during adulthood and aging (11).

Recently, it was shown that levels of ApoE-HDL in the cerebrospinal fluid (CSF), which are believed to play a role in brain plasticity, are similar among E2, E3, and E4 during childhood but higher in adulthood. CSF-ApoE4 then later declines more than the other isoforms (24). These findings suggest a different role of ApoE4 in the brain during early development other than only being deleterious.

Studies by Prentice and Paul (25) have attributed a critical role to fat-enriched diets during the anabolic stage required for physical recovery following enteric infections and malnutrition. In a cohort study in Gambia, they reported that oxidative fat processes are indispensable for production of energy by muscle, which is needed for growth catch-up (26). Furthermore, cholesterol is considered to be a glial-born synaptogenic factor (27) and might play a critical role during synapse remodeling following the brain injury posed by the severe vicious cycle between diarrhea and malnutrition early in life.

Therefore, it is possible to speculate that increased blood levels of LDL-cholesterol obtained from fat-enriched diets, when available, such as breast-milk, and possibly the enhanced cholesterol absorption from the small intestine (28) likely seen in APOE4 carriers (29), and especially in underweight children (30), would support a rapid developmental catch-up required for optimal development and survival. On the other hand, APOE2 carriers (when not contributing to type III hyperlipidemia) would exhibit lower total cholesterol and LDL-cholesterol levels compared to E3 and E4 bearers (31) and would be at high risk of growth faltering.

Furthermore, some investigators have found a protective effect of the APOE4 allele in infectious diseases like severe hepatitis $C(32)$, although most findings show that APOE4 is detrimental when viral infections are present. Conversely, pressure forces of more parasitic and bacterial-born infectious diseases on human population settings (such the 
Great Plague) may have strongly driven the APOE4 allele into the genomic pool (33).

Of note, the time of transition from mixed breast-feeding to weaning, which occurs unusually early in Brazilian shanty town children $(34,35)$, is considered to be a vulnerable window for enteric diseases and recurrent diarrhea.

Therefore, we suggest thatAPOE4 carriers would show an advantage by increasing cholesterol levels when fatenriched diets are insufficient, i.e., during breast-feeding decline, facilitating physical recovery following enteric infections. On the other hand, APOE2 carriers would exhibit lower cholesterol levels and, as demonstrated by our studies, would be at high risk of poor diarrhea and enteric infection outcomes.

Hence the association of APOE2 and increasing diarrhea outcomes demonstrated in our studies would have implications for effective micronutrient intervention, emphasizing the critical importance of direct experimental documentation of these relationships, their causality, and the ability of specific micronutrients to ameliorate the lasting effects of malnutrition and diarrhea.

One potential mechanism involving APOE4 might be the oxidative stress balance during parasitic infection, possibly

\section{References}

1. Checkley W, Gilman RH, Epstein LD, Suarez M, Diaz JF, Cabrera L, et al. Asymptomatic and symptomatic cryptosporidiosis: their acute effect on weight gain in Peruvian children. Am J Epidemiol 1997; 145: 156-163.

2. Guerrant RL, Kosek M, Moore S, Lorntz B, Brantley R, Lima AA. Magnitude and impact of diarrheal diseases. Arch Med Res 2002; 33: 351-355.

3. Lorntz B, Soares AM, Moore SR, Pinkerton R, Gansneder B, Bovbjerg VE, et al. Early childhood diarrhea predicts impaired school performance. Pediatr Infect Dis J 2006; 25: 513-520.

4. Mahley RW, Rall SC Jr. Apolipoprotein E: far more than a lipid transport protein. Annu Rev Genomics Hum Genet 2000; 1: 507-537.

5. Bu G. Apolipoprotein E and its receptors in Alzheimer's disease: pathways, pathogenesis and therapy. Nat Rev Neurosci 2009; 10: 333-344.

6. MCarron MO, Muir KW, Weir CJ, Dyker AG, Bone I, Nicoll $\mathrm{JA}$, et al. The apolipoprotein E epsilon4 allele and outcome in cerebrovascular disease. Stroke 1998; 29: 1882-1887.

7. Graham DI, Horsburgh K, Nicoll JA, Teasdale GM. Apolipoprotein $\mathrm{E}$ and the response of the brain to injury. Acta Neurochir Suppl 1999; 73: 89-92.

8. Wright RO, Hu H, Silverman EK, Tsaih SW, Schwartz J, Bellinger D, et al. Apolipoprotein E genotype predicts 24-month bayley scales infant development score. Pediatr Res 2003; 54: 819-825

9. Oria RB, Patrick PD, Zhang $\mathrm{H}$, Lorntz $\mathrm{B}$, de Castro Costa $\mathrm{CM}$, Brito GA, et al. APOE4 protects the cognitive development in children with heavy diarrhea burdens in Northeast Brazil. Pediatr Res 2005; 57: 310-316. involving arginine transport. Since the arginine selective cationic transporter is up-regulated in the brain neuroglia of APOE4 knock-in mice (36), increased arginine uptake by enterocytes could provide sufficient NO production during enteric infections caused by Giardia lamblia (37), which we and others have found to be mostly correlated with cognitive deficits following diarrhea $(9,38)$, thus enhancing host defenses against enteric infections and diarrhea. Additionally, increased cholesterol availability in the intestinal milieu may enhance innate mucosal immunity by raising the production of pro-inflammatory cytokines such as IL-1 $\beta$ (39). These potential mechanisms are current topics of our ongoing studies.

\section{Acknowledgments}

The authors would like to thank the health workers and the children involved in this project and their families for participating in this study. Research supported in part by the USA National Institutes of Health ICIDR (\#5-UOI Al 26512-14), ABC (\#5D43 TW01136-04), TMRC (\#5 P50 AI30369-09), and FIC (\#TW006713-01) grants, and the Brazilian CNPq support.
10. Turic D, Fisher PJ, Plomin R, Owen MJ. No association between apolipoprotein $\mathrm{E}$ polymorphisms and general cognitive ability in children. Neurosci Lett 2001; 299: 97-100.

11. Oria RB, Patrick PD, Blackman JA, Lima AA, Guerrant RL. Role of apolipoprotein E4 in protecting children against early childhood diarrhea outcomes and implications for later development. Med Hypotheses 2007; 68: 1099-1107.

12. Hubacek JA, Pitha J, Skodova Z, Adamkova V, Lanska V, Poledne R. A possible role of apolipoprotein E polymorphism in predisposition to higher education. Neuropsychobiology 2001; 43: 200-203.

13. Jorm AF, Prior M, Sanson A, Smart D, Zhang Y, Easteal S. Apolipoprotein $\mathrm{E}$ genotype and temperament: a longitudinal study from infancy to the late teens. Psychosom Med 2003; 65: 662-664.

14. Lima AA, Moore SR, Barboza MS Jr, Soares AM, Schleupner MA, Newman RD, et al. Persistent diarrhea signals a critical period of increased diarrhea burdens and nutritional shortfalls: a prospective cohort study among children in northeastern Brazil. J Infect Dis 2000; 181: 1643-1651.

15. Moore SR, Lima AA, Conaway MR, Schorling JB, Soares AM, Guerrant RL. Early childhood diarrhoea and helminthiases associate with long-term linear growth faltering. Int $\mathrm{J}$ Epidemiol 2001; 30: 1457-1464.

16. Zemel BS, Riley EM, Stallings VA. Evaluation of methodology for nutritional assessment in children: anthropometry, body composition, and energy expenditure. Annu Rev Nutr 1997; 17: 211-235.

17. Hixson JE, Vernier DT. Restriction isotyping of human apolipoprotein $\mathrm{E}$ by gene amplification and cleavage with Hhal. J Lipid Res 1990; 31: 545-548. 
18. Oria RB, Costa CM, Lima AA, Patrick PD, Guerrant RL. Semantic fluency: a sensitive marker for cognitive impairment in children with heavy diarrhea burdens? Med Hypotheses 2009; 73: 682-686.

19. Patrick PD, Oria RB, Madhavan V, Pinkerton RC, Lorntz B, Lima AA, et al. Limitations in verbal fluency following heavy burdens of early childhood diarrhea in Brazilian shantytown children. Child Neuropsychol 2005; 11: 233-244.

20. Strittmatter WJ, Bova HC. Molecular biology of apolipoprotein E. Curr Opin Lipidol 2002; 13: 119-123.

21. Huang HC, Jiang ZF. Accumulated amyloid-beta peptide and hyperphosphorylated tau protein: relationship and links in Alzheimer's disease. J Alzheimers Dis 2009; 16: 15-27.

22. Yamauchi K, Tozuka M, Nakabayashi T, Sugano M, Hidaka $\mathrm{H}$, Kondo $\mathrm{Y}$, et al. Apolipoprotein $\mathrm{E}$ in cerebrospinal fluid: relation to phenotype and plasma apolipoprotein $\mathrm{E}$ concentrations. Clin Chem 1999; 45: 497-504.

23. Guerrant RL, Oria R, Bushen OY, Patrick PD, Houpt E, Lima AA. Global impact of diarrheal diseases that are sampled by travelers: the rest of the hippopotamus. Clin Infect Dis 2005; 41 (Suppl 8): S524-S530.

24. Hirayama S, Miida T, Obayashi K, Yamazaki F, YamazakiSakurai M, Ito M, et al. Effect of apolipoprotein E (apoE) phenotype on the apoE content of CSF-HDL in children. Clin Chim Acta 2005; 356: 110-116.

25. Prentice AM, Paul AA. Fat and energy needs of children in developing countries. Am J Clin Nutr 2000; 72: 1253S1265 S.

26. Prentice AM. Early influences on human energy regulation: thrifty genotypes and thrifty phenotypes. Physiol Behav 2005; 86: 640-645.

27. Goritz C, Mauch DH, Nagler K, Pfrieger FW. Role of gliaderived cholesterol in synaptogenesis: new revelations in the synapse-glia affair. J Physiol Paris 2002; 96: 257-263.

28. Kallio MJ, Salmenpera L, Siimes MA, Perheentupa J, Gylling $\mathrm{H}$, Miettinen TA. Apoprotein E phenotype determines serum cholesterol in infants during both high-cholesterol breast feeding and low-cholesterol formula feeding. J Lipid Res 1997; 38: 759-764.

29. Tammi A, Ronnemaa T, Viikari J, Jokinen E, Lapinleimu H, Ehnholm C, et al. Apolipoprotein E4 phenotype increases non-fasting serum triglyceride concentration in infants - the STRIP study. Atherosclerosis 2000; 152: 135-141.

30. Garces C, Benavente M, Ortega H, Rubio R, Lasuncion MA, Rodriguez AF, et al. Influence of birth weight on the apo $E$ genetic determinants of plasma lipid levels in children. $P e-$ diatr Res 2002; 52: 873-878.

31. Srinivasan SR, Ehnholm C, Elkasabany A, Berenson G. Influence of apolipoprotein E polymorphism on serum lipids and lipoprotein changes from childhood to adulthood: the Bogalusa Heart Study. Atherosclerosis 1999; 143: 435443.

32. Wozniak MA, Itzhaki RF, Faragher EB, James MW, Ryder $\mathrm{SD}$, Irving WL. Apolipoprotein E-epsilon 4 protects against severe liver disease caused by hepatitis $C$ virus. Hepatology 2002; 36: 456-463.

33. Mahley RW, Weisgraber KH, Huang Y. Apolipoprotein E: structure determines function, from atherosclerosis to Alzheimer's disease to AIDS. J Lipid Res 2009; 50 (Suppl): S183-S188.

34. Lima AA, Fang G, Schorling JB, De Albuquerque L, Mcauliffe $\mathrm{JF}$, Mota S, et al. Persistent diarrhea in Northeast Brazil: etiologies and interactions with malnutrition. Acta Paediatr 1992; 81 (Suppl) 381: 39-44.

35. Guerrant RL, Oria RB, Moore SR, Oria MO, Lima AA. Malnutrition as an enteric infectious disease with long-term effects on child development. Nutr Rev 2008; 66: 487-505.

36. Czapiga M, Colton CA. Microglial function in human APOE3 and APOE4 transgenic mice: altered arginine transport. $J$ Neuroimmunol 2003; 134: 44-51.

37. Li E, Zhou P, Singer SM. Neuronal nitric oxide synthase is necessary for elimination of Giardia lamblia infections in mice. J Immunol 2006; 176: 516-521.

38. Berkman DS, Lescano AG, Gilman RH, Lopez SL, Black MM. Effects of stunting, diarrhoeal disease, and parasitic infection during infancy on cognition in late childhood: a follow-up study. Lancet 2002; 359: 564-571.

39. Bai B, Yamamoto K, Sato H, Sugiura H, Tanaka T. Combined effect of 25-hydroxycholesterol and IL-1 beta on IL-8 production in human colon carcinoma cell line (Caco-2). Inflammation 2005; 29: 141-146. 